\title{
Nitrous oxide emissions from turfgrass lawns as a result of fertilizer application: a meta-analysis of available literature
}

\author{
Neesha Dutt ${ }^{1,2, *}$ and Tushar Tanwar ${ }^{3}$ \\ ${ }^{1}$ School of Natural Sciences and Engineering, National Institute of Advanced Studies, IISc Campus, Bengaluru 560 012, India \\ ${ }^{2}$ Manipal Academy of Higher Education, Manipal 576 104, India \\ ${ }^{3}$ Indian Institute of Management (IIM)-Bangalore, Bannerghatta Road, Bengaluru 560 076, India
}

\begin{abstract}
Urban turfgrass lawns are known to contribute towards global anthropogenic nitrous oxide emissions. However, available literature on lawn $\mathrm{N}_{2} \mathrm{O}$ emissions is varied and inconclusive. To our knowledge, an effort to compile and understand urban lawn $\mathrm{N}_{2} \mathrm{O}$ emissions is, as yet, lacking. In the present article, a metaanalysis was conducted to evaluate the effect of lawn fertilizer application on $\mathrm{N}_{2} \mathrm{O}$ emissions relative to nofertilizer application, along with an examination of the variation of this effect with respect to the type and amount of fertilizer. The results show that lawn $\mathrm{N}_{2} \mathrm{O}$ emissions from fertilized plots are significant and are $41 \%\left(0.29 \mathrm{~g} \mathrm{~N}_{2} \mathrm{O}-\mathrm{N} / \mathrm{m}^{2} /\right.$ year $)$ higher than that of control plots. However, studies with low $\mathrm{N}$-input ( $<150 \mathrm{~kg} / \mathrm{ha}$ ) show higher percentage (40) of $\mathrm{N}_{2} \mathrm{O}$ emission than those with high $\mathrm{N}$-input (22). Further, $\mathrm{N}_{2} \mathrm{O}$ emissions are higher for urea application plots (37\%) compared to other-than-urea plots (30\%), which consisted mostly of enhanced efficiency fertilizer plots. Overall, the results of this meta-analysis underscore current understandings of the effect of fertilizer on soil $\mathrm{N}_{2} \mathrm{O}$ emissions, although it indicates that fertilizer amount is not the only driver of lawn $\mathrm{N}_{2} \mathrm{O}$ emissions. Also, the sub-group analysis of fertilizer type reinforces the importance of enhanced efficiency fertilizers in reducing emissions which has clear policy implications. To improve our understanding of lawn $\mathrm{N}_{2} \mathrm{O}$ emissions, more long-term studies that are welldocumented, and geographically widespread, are recommended to build a database that can reduce uncertainties and facilitate long-term evaluations.
\end{abstract}

Keywords: Fertilizer, meta-analysis, nitrous oxide, turfgrass lawn, urban.

ModifiCATION of the nitrogen $(\mathrm{N})$ cycle due to human activities such as $\mathrm{N}$ fertilizer application can increase atmospheric nitrous oxide $\left(\mathrm{N}_{2} \mathrm{O}\right)$ concentrations ${ }^{1,2}$. Nitrous oxide acts as a powerful greenhouse gas ${ }^{3,4}$ which is 265 times more effective than carbon dioxide $\left(\mathrm{CO}_{2}\right)$ on a 100 -year time scale ${ }^{5}$. It is also a major ozone depleting

\footnotetext{
*For correspondence. (e-mail: neeshadutt@gmail.com)
}

substance, has increased its atmospheric concentration by $20 \%$ since pre-industrial times with a growth rate of $0.77 \mathrm{ppbv} / \mathrm{year}$ between 2001 and 2009, and has a residence time of approximately 120 years ${ }^{6,7}$.

Global $\mathrm{N}_{2} \mathrm{O}$ estimates show that majority of the anthropogenic $\mathrm{N}_{2} \mathrm{O}$ emissions (approx. 60\%) is attributed to agriculture ${ }^{7,8}$. As anthropogenic $\mathrm{N}_{2} \mathrm{O}$ emissions are projected to almost double $\left(9.7 \mathrm{Tg} \mathrm{N}_{2} \mathrm{O}-\mathrm{N} /\right.$ year) by 2050 from their estimated value in 2005 (ref. 9), research on the impact of agricultural management practices on $\mathrm{N}_{2} \mathrm{O}$ emissions has increasingly gained momentum in scholarly literature. In comparison, studies on urban lawn management practices and their ensuing atmospheric emissions are much less in number. Urban turfgrass lawns are associated with high levels of water and fertilizer applications, similar to agricultural ecosystems, and can thus emit considerable amounts of $\mathrm{N}_{2} \mathrm{O}$ (refs 10 and 11). For example, mean $\mathrm{N}_{2} \mathrm{O}$ emissions from turfgrass lawns can range from 0.002 to $4.1 \mathrm{~g} \mathrm{~N}_{2} \mathrm{O}-\mathrm{N} / \mathrm{m}^{2} /$ year for $\mathrm{N}$ applications between 5 and $120 \mathrm{~g} \mathrm{~N} / \mathrm{m}^{2} /$ year (Supplementary Table 1). Again, mean annual $\mathrm{N}_{2} \mathrm{O}$ emissions, measured in $\mathrm{g} \mathrm{N}_{2} \mathrm{O}-\mathrm{N} / \mathrm{m}^{2} /$ year, from fertilized turfgrass (0.27), grasslands (0.46) and cropping systems (0.35) are comparable $^{12}$.

At present, there are no reliable published global estimates of the area occupied by turfgrass. However, being a dominant land cover in the USA ${ }^{13,14}$ and a prominent green space in other countries ${ }^{15-17}$, lawn emissions could be significant. For example, Kaye et al. ${ }^{10}$ show that $6.4 \%$ of land occupied by urban lawns could be responsible for $30 \%$ of regional $\mathrm{N}_{2} \mathrm{O}$ emissions in Larimer County, Colorado, USA. Similarly, Robbins and Berkenholtz ${ }^{13}$ show that the percentage of urban lawn area in Franklin County, Ohio, USA (23) is only set to increase, with more land being converted for urban development. Still further, at the continental scale, Milesi et al. ${ }^{14}$ found that turfgrass is the largest irrigated crop in the USA, occupying $1.9 \%$ of continental United States wherein urban area is purported to constitute between $3.5 \%$ and $4.9 \%$ of the total land area. In the city of Bengaluru, India, resource intensive lawn spaces can be found in residential, office, sports, commercial and institutional establishments to 
Table 1. Sorting of database: availability of data for meta-analysis (12 studies meet all four column criteria). Details of database sorting in Supplementary Table 3

\begin{tabular}{|c|c|c|c|c|}
\hline Study & $\begin{array}{c}\text { Urban } \\
\text { turfgrass lawn }\end{array}$ & $\begin{array}{c}\text { Measurement } \\
\text { technique }\end{array}$ & $\begin{array}{l}\text { Fertilizer } \\
\text { treatment plot }\end{array}$ & Control plot \\
\hline \multicolumn{5}{|l|}{ Journal articles } \\
\hline Matthias et al..$^{33}$ & $\checkmark$ & $\checkmark$ & $\checkmark$ & $\checkmark$ \\
\hline Bergstorm et al. ${ }^{25}$ & $\checkmark$ & $\checkmark$ & $\checkmark$ & $\checkmark$ \\
\hline Livesley et al. ${ }^{34}$ & $\checkmark$ & $\checkmark$ & $\checkmark$ & $\checkmark$ \\
\hline Raciti et al. ${ }^{24}$ & $\checkmark$ & $\checkmark$ & $\checkmark$ & $\checkmark$ \\
\hline McPhillips et al. $^{35}$ & $\checkmark$ & $\checkmark$ & $\checkmark$ & $\checkmark$ \\
\hline LeMonte et al..$^{31}$ & $\checkmark$ & $\checkmark$ & $\checkmark$ & $\checkmark$ \\
\hline Gillette et $a l .^{32}$ & $\checkmark$ & $\checkmark$ & $\checkmark$ & $\checkmark$ \\
\hline \multicolumn{5}{|l|}{ Non-journal articles } \\
\hline Crane $^{30}$ & $\checkmark$ & $\checkmark$ & $\checkmark$ & $\checkmark$ \\
\hline Garrison and Soldat ${ }^{36}$ & $\checkmark$ & $\checkmark$ & $\checkmark$ & $\checkmark$ \\
\hline Walker and Smith ${ }^{37}$ & $\checkmark$ & $\checkmark$ & $\checkmark$ & $\checkmark$ \\
\hline Braun and Bremer ${ }^{38}$ & $\checkmark$ & $\checkmark$ & $\checkmark$ & $\checkmark$ \\
\hline Nahas et al. ${ }^{39}$ & $\checkmark$ & $\checkmark$ & $\checkmark$ & $\checkmark$ \\
\hline
\end{tabular}

Table 2. Classification of fertilizer based on amount ( $\mathrm{kg} / \mathrm{ha})$ and type (urea versus other than urea)

\begin{tabular}{|c|c|c|}
\hline Study* & $\begin{array}{l}\text { Amount of fertilizer } \\
\qquad(\mathrm{kg} / \mathrm{ha})\end{array}$ & $\begin{array}{c}\text { Type of fertilizer } \\
\text { (urea versus other than urea) }\end{array}$ \\
\hline LeMonte et al..$^{31}$ site 1 PCU & 200 & Other than urea \\
\hline LeMonte et al..$^{31}$ site 1 urea & 200 & Urea \\
\hline LeMonte et $a l . .^{31}$ site 2 PCU & 200 & Other than urea \\
\hline LeMonte et al..$^{31}$ site 2 urea & 200 & Urea \\
\hline Braun and Bremer ${ }^{38}$ PCU & 97 & Other than urea \\
\hline Braun and Bremer ${ }^{38}$ urea & 97 & Urea \\
\hline Livesley et $a l .{ }^{34}$ rain & 220 & Other than urea \\
\hline Livesley et al. ${ }^{34}$ irrigation & 220 & Other than urea \\
\hline Matthias et al. ${ }^{33}$ site 2 & $\mathrm{NK}^{* *} *$ & $\mathrm{NK}$ \\
\hline Raciti et al. $^{24}$ & 98 & Other than urea \\
\hline Walker and Smith ${ }^{37}$ HT & 221 & Urea \\
\hline Walker and Smith ${ }^{37} \mathrm{CT}$ & 221 & Urea \\
\hline Walker and Smith $^{37}$ VC & 221 & Urea \\
\hline Gillette $^{32}$ umaxx & 150 & Other than urea \\
\hline Gillette $\mathrm{e}^{32}$ polyon & 150 & Other than urea \\
\hline Gillette $^{32}$ BCMU & 150 & Other than urea \\
\hline McPhillips et $a .^{35}$ & $\mathrm{NK}$ & $\mathrm{NK}$ \\
\hline Crane $^{30}$ site $\mathrm{A}$ & NK & NK \\
\hline Crane $^{30}$ site B & NK & $\mathrm{NK}$ \\
\hline Crane $^{30}$ site C & NK & NK \\
\hline Garrison and Soldat $^{36}$ & 47 & Urea \\
\hline Garrison and Soldat ${ }^{36}$ (organic) & 47 & Other than urea \\
\hline Bergstorm et al. ${ }^{25} \mathrm{AS}$ & 100 & Other than urea \\
\hline Bergstorm et al. $^{25} \mathrm{CAN}$ & 100 & Other than urea \\
\hline Bergstorm et al. $^{25} \mathrm{URE}$ & 100 & Urea \\
\hline Nahas et al. ${ }^{39}$ urea low & 36.5 & Urea \\
\hline Nahas et al. ${ }^{39}$ urea high & 73 & Urea \\
\hline
\end{tabular}

*PCU, polymer coated urea; BCMU, balance chain methylene urea; AS, ammonium sulphate; CAN, calcium nitrate; HT, hollow-tine aerification; VC, verticutting; CT, no cultivation/untreated control. **NK: not known/no data.

varying degrees, often constituting a principal component of the landscape, particularly as part of urban real estate development projects along the city's periphery ${ }^{18}$. Together, these studies suggest that understanding lawn $\mathrm{N}_{2} \mathrm{O}$ emissions is relevant given their prominent urban spatial extents and, moderate-to-high emission levels.

However, this is a nascent field of research and lawn $\mathrm{N}_{2} \mathrm{O}$ studies are few. Within the limited studies that are available, there is little consensus on $\mathrm{N}_{2} \mathrm{O}$ emissions from turfgrass. Due to high spatial and temporal variability, the magnitude of lawn $\mathrm{N}_{2} \mathrm{O}$ emissions differ across studies (Supplementary Table 1). Also, there is uncertainty associated with how environmental factors (for example, climate, precipitation, soil physico-chemical parameters) and lawn management practices (for example, $\mathrm{N}$ fertilizer application rates, irrigation, mowing activities) influence 
emissions. This highlights the fact that so far, research pertaining to lawn $\mathrm{N}_{2} \mathrm{O}$ emissions and their controlling factors remains inconclusive. To our knowledge, an effort to compile and understand urban lawn $\mathrm{N}_{2} \mathrm{O}$ emission studies is, as yet, lacking. To address this gap, we posit that a meta-analysis approach can help integrate findings from individual studies in a meaningful way that could reveal new insights, confirm existing suspicions and organize future work in this field of research. A metaanalysis, study of studies, is a statistical method which combines the magnitude of outcomes (i.e. effect sizes) across individual studies involving the same research question $^{19}$. In this way, it increases the statistical power of the analysis over that of individual studies, improves the estimation of the size of the effect under study and removes uncertainty associated with differing results ${ }^{19-21}$. At present, meta-analysis studies on direct soil $\mathrm{N}_{2} \mathrm{O}$ emissions are mainly from agriculture, grassland and forest ecosystems. Therefore, the aim of this article is to present a meta-analysis on urban lawn $\mathrm{N}_{2} \mathrm{O}$ emissions for the first time from available literature. The primary objective of the meta-analysis is to evaluate the effect of fertilizer application on $\mathrm{N}_{2} \mathrm{O}$ emissions relative to no-fertilizer application in turfgrass lawns. In addition, variation of this effect with respect to the type and amount of fertilizer application was also examined.

\section{Materials and methods}

\section{Data sources}

Lawn $\mathrm{N}_{2} \mathrm{O}$ emission studies were compiled through search engines such as Google, and Google Scholar; and also from bibliographies of agricultural $\mathrm{N}_{2} \mathrm{O}$ summary papers till September 2019. Since the dataset on studies that focus only on direct lawn $\mathrm{N}_{2} \mathrm{O}$ was limited, data search was also conducted for work on lawn/grass plots that were measured for direct emissions as part of a larger study where the main focus was not lawn $\mathrm{N}_{2} \mathrm{O}$ emissions. A mix of search terms were used: nitrous oxide + turfgrass + lawn; $\quad \mathrm{N}_{2} \mathrm{O}+$ urban + turfgrass; greenhouse gas + soil emission + lawn. Both peer-reviewed as well as non-peer reviewed articles were included. Therefore, university extension publications and reports formed a sizable portion of the non-peer reviewed database (Table 1). Inclusion of all forms of available data is encouraged in meta-analysis because often, experimental data go unreported due to insignificance; these insignificant outcomes, however, are valuable in meta-analysis to arrive at a truer conclusion of the overall effect of the phenomenon ${ }^{22}$. Next, keeping the primary objective in mind, the database was sorted according to three criteria for inclusion in the meta-analysis: (a) the $\mathrm{N}_{2} \mathrm{O}$ measurement study should have been for an urban turfgrass lawn or urban grass site that is managed (fertilized, irrigated and/mowed); (b) the emission measurements should be done using field-based methods that capture $\mathrm{N}_{2} \mathrm{O}$ emissions directly. This included closed static chamber method, both manual and automatic sampling (38 out of 41); and $\mathrm{N}_{2} \mathrm{O}$ field gas analyser (2 studies out of 41). Eddy covariance and micrometeorological studies were excluded; (c) there should be at least one control plot (zero fertilizer plot) against a non-zero fertilizer treatment plot (all other conditions being the same) for emission measurements across the sampling period.

\section{Data extraction}

There were 12 studies out of the identified 41 direct $\mathrm{N}_{2} \mathrm{O}$ lawn studies that could be included in the analysis (Table 1). The main reasons for exclusion were unreported data (NK), absence of control plots, and unclear/low resolution emission graphs from which data could not be extracted (unavailable data). For each selected study, all comparisons between fertilizer and no fertilizer treatments for mean $\mathrm{N}_{2} \mathrm{O}$ emissions were separately included in the meta-analysis. As such, the resulting database has 27 observations from 12 selected studies in the final meta-analysis dataset (Figures 1 and 2). $\mathrm{N}_{2} \mathrm{O}$ emission data were extracted from text and/available figures and graphs. Web Plot Digitizer (free version) was used to accurately note down values of $(x, y)$ points in the graphs. All $\mathrm{N}_{2} \mathrm{O}$ flux conversions were in units of $\mu \mathrm{g} \mathrm{N}_{2} \mathrm{O}$ $\mathrm{N} / \mathrm{m}^{2} / \mathrm{h}$.

Additional information from the final database allowed an examination of how the fertilizer effect on $\mathrm{N}_{2} \mathrm{O}$ emission varies with respect to the type and amount of fertilizer. Hence, based on the median range of $\mathrm{N}$ fertilizer input in the selected database, $>150 \mathrm{~kg} / \mathrm{ha}$ was assigned as high $\mathrm{N}$-input and $<150 \mathrm{~kg} / \mathrm{ha}$ was assigned as low $\mathrm{N}$ input (Table 2). Similarly, based on the type used in the selected studies, fertilizers were categorized as synthetic fertilizers (for example urea), enhanced efficiency fertilizers (EEF) and organic fertilizers. In the selected database, there were 12,9 and 1 application of synthetic fertilizers, EEF and organic fertilizers respectively (Table 2 ). Within the synthetic fertilizer category, 10 were urea applications and one application each of ammonium sulphate (AS) and calcium nitrate (CAN).

\section{Data analysis}

The natural $\log (\ln R)$ of the response ratio was used to calculate effect size ${ }^{21}$ to estimate the magnitude and direction of $\mathrm{N}$ fertilizer effects on $\mathrm{N}_{2} \mathrm{O}$ emissions

$$
\ln (R)=\ln \left(\frac{\bar{X}_{N}}{\bar{X}_{C}}\right),
$$

where $\bar{X}_{N}$ and $\bar{X}_{C}$ are the mean $\mathrm{N}_{2} \mathrm{O}$ emission values for the $\mathrm{N}$ fertilizer and control treatments respectively. 


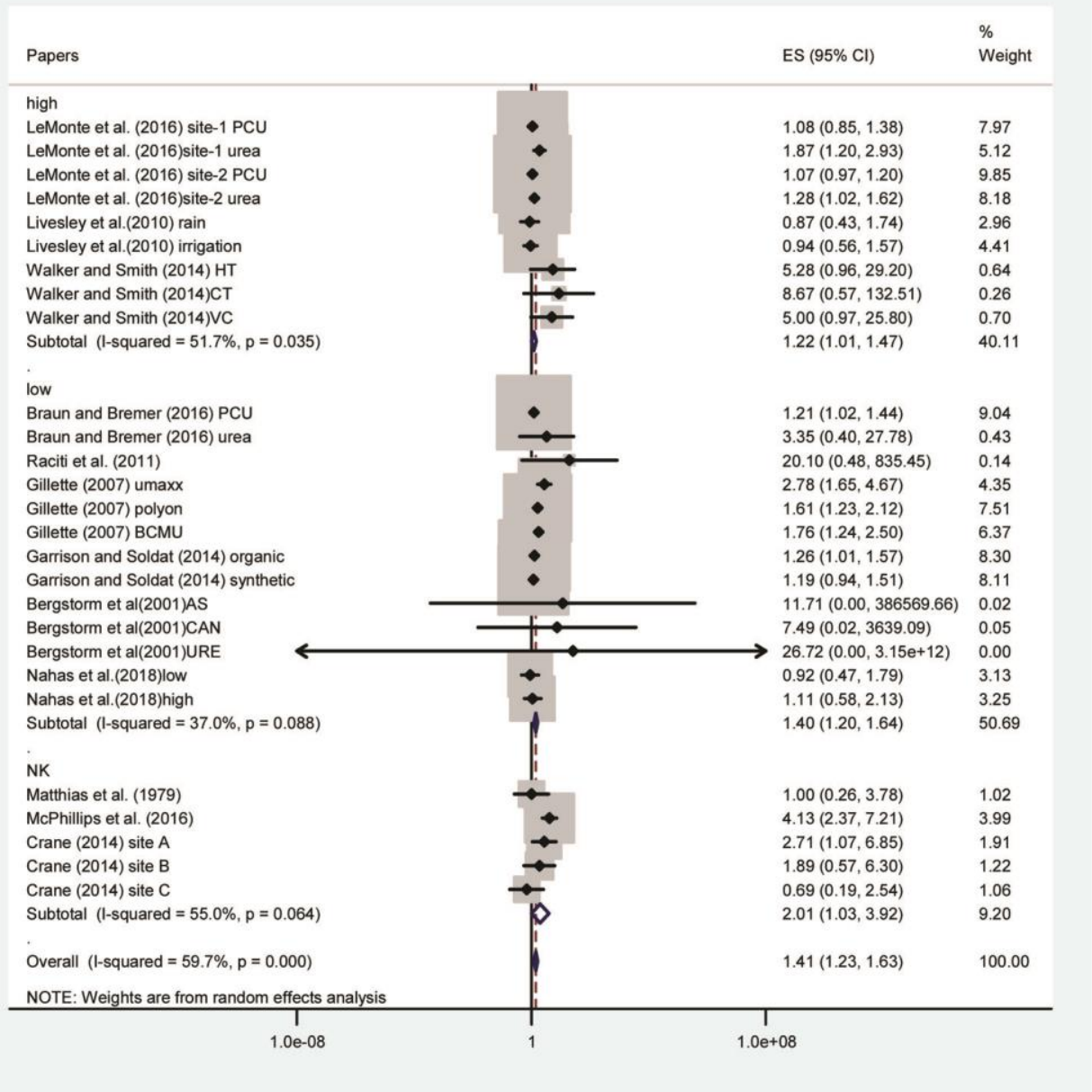

Figure 1. Effect of fertilizer application on lawn $\mathrm{N}_{2} \mathrm{O}$ emissions: $(\boldsymbol{a})$ summary effect $(1.41)$ and $(\boldsymbol{b})$ by fertilizer amount (high, low).

Stata statistical software ${ }^{23}$ was used to calculate mean effect sizes (ES) and generate $95 \%$ confidence intervals (CIs) (Figures 1 and 2). So, for each of the 27 observations, mean, standard deviation and sample sizes were calculated along with pooled deviation, response ratio $(R), \log$ response ratio $(\ln R)$ and its variance and standard error (SE) (Supplementary Table 2). The results for the analysis on $\ln R$ were back-transformed and reported as percentage change under fertilizer treatment $(T)$ relative to control $(C)$. Treatment effects were considered to be significant if the $95 \%$ CI did not overlap with zero.

\section{Results}

In all of the 27 comparisons from 12 different studies, the difference between fertilizer treatment and control plot emissions were significant $(P<0.05 \%)$ indicating that $\mathrm{N}_{2} \mathrm{O}$ emissions were greater when fertilizers were applied. The summary effect of 1.41 shows that the combined effect of fertilizer application from the set of selected studies is positive for $\mathrm{N}_{2} \mathrm{O}$ emissions and that $\mathrm{N}_{2} \mathrm{O}$ emissions are $41 \%$ higher than that of control plots (Figures 1 and 2). In absolute terms, this translates to fertilizer plot emissions being higher by $0.29 \mathrm{~g} \mathrm{~N}_{2} \mathrm{O}-\mathrm{N} / \mathrm{m}^{2} /$ year with respect to control plot emissions $\left(0.65 \mathrm{~g} \mathrm{~N}_{2} \mathrm{O}-\right.$ $\mathrm{N} / \mathrm{m}^{2} /$ year) in the selected dataset. The fact that fertilizer application has a positive effect on $\mathrm{N}_{2} \mathrm{O}$ emissions was as expected. However, contrary to what is usually expected, Figure 1 also shows that studies with low $\mathrm{N}$-input $\left(<150 \mathrm{~kg} / \mathrm{ha}\right.$ ) show a higher percentage (1.40) of $\mathrm{N}_{2} \mathrm{O}$ emissions than those with high $\mathrm{N}$-input (1.22). This implies that $\mathrm{N}_{2} \mathrm{O}$ emissions are higher when fertilizer inputs are lower and vice versa. Two outliers might be the studies by Raciti et al. ${ }^{24}$ and Bergstorm et al. ${ }^{25}$ as the precision for these studies is very low. However, despite removing these studies as outliers, the overall trend of lower input-higher emissions remained the same. In terms of type of fertilizer, Figure 2 shows that $\mathrm{N}_{2} \mathrm{O}$ emissions are higher for urea application plots (1.37) compared to other-than-urea plots category (1.30). Since EEFs were used for 9 out of the 12 other-than-urea plots, it follows that EEFs may largely be responsible for this finding. This was an expected outcome as EEFs are 


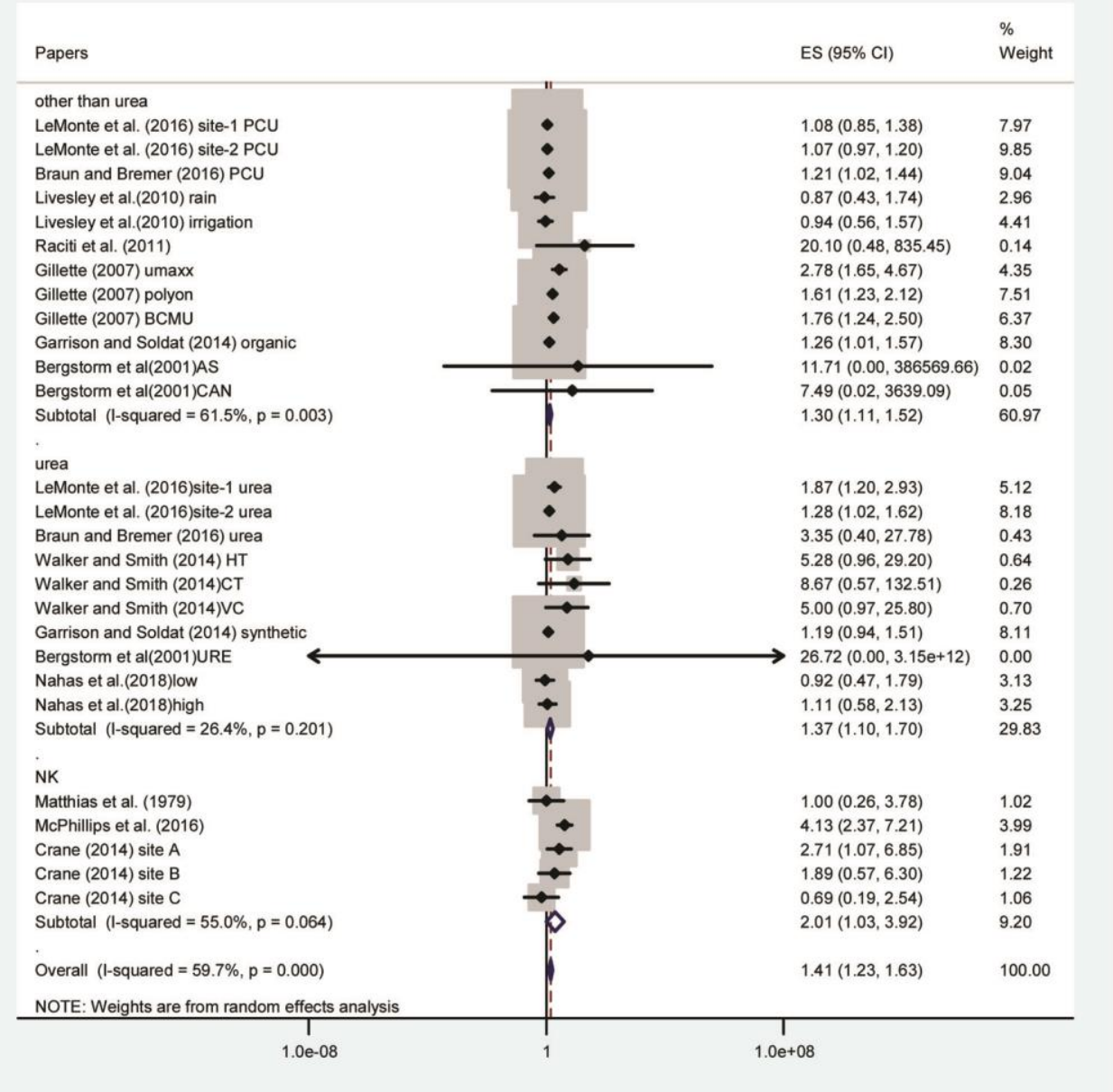

Figure 2. Effect of fertilizer application on lawn $\mathrm{N}_{2} \mathrm{O}$ emissions: (a) summary effect (1.41) and (b) by fertilizer type (urea, other than urea).

expected to release $\mathrm{N}$ more efficiently for plant uptake ${ }^{26}$. Further, the fertilizer induced $\mathrm{N}_{2} \mathrm{O}$ emission factor was similar across studies averaging $0.11 \%$ which is notably less than the default IPCC $\mathrm{N}_{2} \mathrm{O}$ emission factor of $1 \%$ proposed globally for cropland systems managed with synthetic fertilizers.

An important aspect of a meta-analysis is to ascertain whether the effect size is consistent (homogeneous) or varied (heterogeneous) across all the studies in the selected dataset. In Figures 1 and 2, overall, the heterogeneity or $I^{2}$ statistic is significant at $59.7 \%$. This indicates that the effect is heterogeneous across the range of studies in the selected database and that, the level of heterogeneity, in relative terms, is moderate $\left(I^{2}\right.$ values in the order of $25 \%, 50 \%$ and $75 \%$ are considered low, moderate and high respectively ${ }^{21}$. This heterogeneity could be due to factors that influence emissions such as the amount of fertilizer, the type of fertilizer, and soil physico-chemical parameters. However, the sub-group analysis for fertilizer amount (Figure 1) and fertilizer type (Figure 2) do not provide an explanation for this heterogeneity in overall effect size; this is because there was still some level of heterogeneity ( $I^{2}$ is not equal to zero) exhibited by the subgroups. This implies that factors other than fertilizer amount and fertilizer type may be responsible for the overall dispersion or variation in effect sizes across individual studies in the selected dataset. Therefore, a more robust explanation for the sub-group analysis results would be possible only if data for influencing factors other than fertilizer amount and type - for example, soil moisture, soil temperature, $\mathrm{pH}$, soil nitrate, etc. were available in future analysis.

It should also be noted that while all 27 observations contributed towards a significant overall effect size of 1.41 for lawn $\mathrm{N}_{2} \mathrm{O}$ emissions, this was not so for all categories within each sub-group (fertilizer amount and fertilizer type). A set of observations within the sub-groups had to be grouped under the not known (NK) category due to lack of reported values in the individual studies. As such the effect size (sub-total value) of the NK category within each sub-group (fertilizer amount and type) is of no significance. This is contrary to the effect sizes of 
the other four sub-group categories (high, low, urea, other-than-urea) which have yielded useful insights as discussed below.

\section{Discussion}

Consistent with previous meta-analysis studies on soil $\mathrm{N}_{2} \mathrm{O}$ emissions from agriculture ${ }^{27,28}$, it was found that overall, $\mathrm{N}_{2} \mathrm{O}$ emissions increase with fertilizer application. This is the first attempt to summarize and understand urban lawn $\mathrm{N}_{2} \mathrm{O}$ emissions using a meta-analysis approach; hence there are no other urban lawn metaanalysis studies to compare this with. Also, given the limited number of observations in the dataset, with 24 out of 27 observations from the USA alone, this inference is open to further analysis and interpretation as and when more results from lawn $\mathrm{N}_{2} \mathrm{O}$ studies are available in future from other geographic regions.

The finding that stood out was the fact that the effect size resulting from fertilizer treatment was higher for low fertilizer application plots than for high fertilizer application plots. This finding is a noteworthy departure from the norm. A possible explanation could be as follows. Poorly drained and poorly aerated soils are known to emit higher $\mathrm{N}_{2} \mathrm{O}$ especially if fertilization events occur closer to rainfall/irrigation events ${ }^{24,27}$. In such situations $\mathrm{N}_{2} \mathrm{O}$ emissions can often peak after heavy storm/irrigation events post-fertilization. For the result found in this metaanalysis study, it could be that the tendency of fertilizer to get washed away is higher for higher fertilizer inputs in the event of a rainfall than that for lower fertilizer input; also higher $\mathrm{N}$ applications may be accompanied by higher water applications further facilitating this outcome. Groffman et al. $^{29}$ found similar results in their study and suggested that a difference in water inputs rather than fertilizer inputs drive lawn $\mathrm{N}_{2} \mathrm{O}$ emissions and should therefore be simultaneously examined. They also pointed out that even though denitrification is a dominant pathway for $\mathrm{N}_{2} \mathrm{O}, \mathrm{N}$ losses could occur as $\mathrm{N}_{2}$ or NO flux instead of $\mathrm{N}_{2} \mathrm{O}$. In addition, they alluded to the possibility of missing information due to their inability to capture emissions around fertilization events in the study. In a similar vein, Crane ${ }^{30}$, found lower $\mathrm{N}_{2} \mathrm{O}$ emissions from fertilized lawn plots versus unfertilized control plots; they further noted that soil $\mathrm{pH}$ at the fertilized plot was lower (5.8, acidic soil) than that of the other plots (6.7, acidic soil). Given that $\mathrm{N}_{2} \mathrm{O}$ emissions tend to increase in low soil $\mathrm{pH}$ conditions ${ }^{27}$, $\mathrm{Crane}^{30}$, finally explained the contradiction in their finding by suggesting that low soil $\mathrm{pH}$ may inhibit nitrate, thus stopping denitrification and lowering $\mathrm{N}_{2} \mathrm{O}$ emissions. For our meta-analysis, as data for factors like soil texture, soil moisture, soil $\mathrm{pH}$ and water inputs were scarce, examining their association with $\mathrm{N}_{2} \mathrm{O}$ flux was not possible. This indicates the need for improving the reporting of such values in literature.
The next significant finding was that $\mathrm{N}_{2} \mathrm{O}$ emission are higher for urea application plots than EEF applied and organic plots. This is consistent with the fact that EEFs release $\mathrm{N}$ more efficiently for plant uptake and organic applications are known to have lower environmental impact. Therefore, recommendations for using EEFs and organic inputs could help reduce $\mathrm{N}_{2} \mathrm{O}$ emission levels. Another point to note here is that in spite of a sports turf being more resource intensive than an aesthetic turf and thus expected to emit more $\mathrm{N}_{2} \mathrm{O}$, emissions between sports turf and aesthetic turf were similar in EEF plots in the LeMonte et al. ${ }^{31}$ study. Also, based on two of the selected studies (refs 31,32) higher effect sizes were found for EEFs such as UMaxx, Polyon and BCMU as opposed to the more commonly applied polymer coated urea (PCU) indicating that PCU might be a better choice among these EEFs for emission reduction.

\section{Conclusion}

\section{Summary}

The major findings from this meta-analysis firstly reveal that $\mathrm{N}_{2} \mathrm{O}$ emissions increase significantly (41\%) with $\mathrm{N}$ application in urban turfgrass lawns. This is in compliance with current understandings of the effect of fertilizer on soil $\mathrm{N}_{2} \mathrm{O}$ emissions. Secondly, the sub-group analysis for fertilizer amount implies that lawn $\mathrm{N}_{2} \mathrm{O}$ emissions are higher (40\%) when fertilizer inputs are lower ( $<150 \mathrm{~kg} / \mathrm{ha})$ and vice versa; this finding corroborates with a set of alternate findings in literature that caution against considering $\mathrm{N}$ amount alone as the only important driver of soil $\mathrm{N}_{2} \mathrm{O}$ emissions. Thirdly, the sub-group analysis for fertilizer type shows that $\mathrm{N}_{2} \mathrm{O}$ emissions are higher for urea application plots (37\%) in comparison with other-than-urea plots category (30\%); this finding reinforces the importance of enhanced efficiency fertilizers in reducing emissions and has clear policy implications. Further, there was a moderate level of heterogeneity $\left(I^{2}=59.7 \%\right)$ in the overall effect which could not be explained by either fertilizer amount or fertilizer type. This implies that factors other than the type and amount of fertilizer maybe responsible for this dispersion of effects across studies; this, in turn, emphasizes the need for data availability in terms of other influencing factors such as soil moisture, soil temperature, soil nitrate, etc.

\section{Strengths and limitations of the study}

Given that lawn spaces occupy extensive areas and also emit $\mathrm{N}_{2} \mathrm{O}$, the present article addresses a pertinent yet understudied issue - that of urban lawn $\mathrm{N}_{2} \mathrm{O}$ emissions. It presents the first meta-analysis on urban lawn $\mathrm{N}_{2} \mathrm{O}$ emissions by attempting to integrate findings from existing 
studies in a meaningful way to reveal useful insights. For a more robust analysis, non-peer reviewed publications were included in the final dataset to address publication bias and avoid leaving out insignificant outcomes that could ultimately help arrive at a closer estimate of true emissions. Further, outlier studies with low precision levels were systematically removed to ascertain that they did not influence the overall results unduly.

Interestingly, the final results of the analysis underscored an important limitation. Apart from the importance of understanding what the summary effect conveyed, the presence of a moderate level of heterogeneity indicated the need to understand the reasons behind this heterogeneity as well. To elaborate, although the overall effect size of 1.41 is significant and positive for lawn fertilizer $\mathrm{N}_{2} \mathrm{O}$ emissions, based on the nature and amount of available data, this study suggests that it is also essential to focus on the influencing factors behind this heterogeneity than focus only on the summary effect. As fertilizer amount and fertilizer type could not explain the variation or heterogeneity in effect sizes found in this analysis, an important limitation is the absence of data on other influencing factors such as soil temperature, moisture, $\mathrm{pH}$, bulk density, etc.

Again, apart from the non-availability of data on influencing factors, the number of available lawn $\mathrm{N}_{2} \mathrm{O}$ studies is limited, geographically biased towards temperate regions and incomplete due to unreported values, illegible graphs/unextractable data and absence of control plot data, making it difficult to generalize the results obtained in this meta-analysis. Also, experimental studies conducted for no longer than a year may have failed to capture temporal variations of $\mathrm{N}_{2} \mathrm{O}$. In view of these limitations, it becomes important to build a database that synthesizes more research in this area that has a wide geographical base, uniformly follows protocol, increases transparency of reported values and figures, and consistently produces peer-reviewed publications for greater visibility, improved access, outreach and recognition. In other words, to improve our understanding further, more robust, well documented, longer-term studies from different world regions are required to build a stronger database for long-term evaluations and reducing uncertainties.

1. Galloway, J. N., Aber, J. D., Erisman, J. W., Seitzinger, S. P., Howarth, R. W., Cowling, E. B. and Cosby, B. J., The nitrogen cascade. AIBS Bull., 2003, 53, 341-356.

2. Fowler, D., Coyle, M., Skiba, U., Sutton, M. A., Cape, J. N., Reis, S. and Vitousek, P., The global nitrogen cycle in the twenty-first century. Philos. Trans. R. Soc. Lond. B, 2013, 368, 20130164.

3. Wang, W., Haver, D. and Pataki, D. E., Nitrogen budgets of urban lawns under three different management regimes in southern California. Biogeochemistry, 2014, 121, 127-148.

4. Bouwman, A. F., Beusen, A. H. W., Griffioen, J., Van Groenigen, J. W., Hefting, M. M., Oenema, O. and Stehfest, E., Global trends and uncertainties in terrestrial denitrification and $\mathrm{N}_{2} \mathrm{O}$ emissions. Philos. Trans. R. Soc. London B, 2012, 368, 20130112.

5. Ciais, P. et al., Carbon and other biogeochemical cycles. In Climate Change 2013: The Physical Science Basis. Contribution of Working Group I to the Fifth Assessment Report of the Intergovernmental Panel on Climate Change (eds Stocker, T. F. et al.), Cambridge University Press, Cambridge, United Kingdom and New York, NY, USA, 2013.

6. Butterbach-Bahl, K., Baggs, E. M., Dannenmann, M., Kiese, R. and Zechmeister-Boltenstern, S., Nitrous oxide emissions from soils: how well do we understand the processes and their controls? Philos. Trans. R. Soc. London B, 2013, 368, 20130122.

7. Smith, K. A., Changing views of nitrous oxide emissions from agricultural soil: key controlling processes and assessment at different spatial scales. Eur. J. Soil Sci., 2017, 68, 137-155.

8. Syakila, A. and Kroeze, C., The global nitrous oxide budget revisited. Greenhouse Gas Measure. Manage., 2011, 1, 17-26.

9. Davidson, E. A. and Kanter, D., Inventories and scenarios of nitrous oxide emissions. Environ. Res. Lett., 2004, 9, 105012.

10. Kaye, J. P., Burke, I. C., Mosier, A. R. and Pablo Guerschman, J., Methane and nitrous oxide fluxes from urban soils to the atmosphere. Ecol. Appl., 2004, 14, 975-981.

11. Townsend-Small, A., Pataki, D. E., Czimczik, C. I. and Tyler, S. C., Nitrous oxide emissions and isotopic composition in urban and agricultural systems in southern California. J. Geophys. Res.: Biogeosci., 2011, 116.

12. Braun, R. C. and Bremer, D. J., Nitrous oxide emissions in turfgrass systems: a review. Agron. J., 2018, 110, 2222-2232.

13. Robbins, P. and Birkenholtz, T., Turfgrass revolution: measuring the expansion of the American lawn. Land Use Policy, 2003, 20, 181-194.

14. Milesi, C., Running, S. W., Elvidge, C. D., Dietz, J. B., Tuttle, B. T. and Nemani, R. R., Mapping and modeling the biogeochemical cycling of turf grasses in the United States. Environ. Manage., 2005, 36, 426-438.

15. Stewart, G. H., Ignatieva, M. E., Meurk, C. D., Buckley, H., Horne, B. and Braddick, T., URban Biotopes of Aotearoa New Zealand (URBANZ)(I): composition and diversity of temperate urban lawns in Christchurch. Urban Ecosyst., 2009, 12, 233-248.

16. Koch, N., The violence of spectacle: Statist schemes to green the desert and constructing Astana and Ashgabat as urban oases. Soc. Cult. Geogr., 2015, 16, 675-697.

17. Ignatieva, M., Ahrné, K., Wissman, J., Eriksson, T., Tidåker, P., Hedblom, M. and Bengtsson, J., Lawn as a cultural and ecological phenomenon: a conceptual framework for transdisciplinary research. Urban Forest. Urban Green., 2015, 14, 383-387.

18. Dutt, N., Being Green? Seminar, 2017, 694, 50-54.

19. Koricheva, J., Gurevitch, J. and Mengersen, K. (eds), Handbook of Meta-Analysis in Ecology and Evolution, Princeton University Press, 2013.

20. Last, J. M., Abramson, J. H. and Freidman, G. D. (eds), A Dictionary of Epidemiology, Oxford University Press, New York, 2001.

21. Borenstein, M., Hedges, L. V., Higgins, J. and Rothstein, H. R. (eds), References, John Wiley, 2009, pp. 409-414.

22. Fisher, M., Moving science through: meta-analysis. Crops, Soils, Agron. News, 2015, 60, 4-9.

23. StataCorp, Stata Statistical Software: Release 12, College Station, TX: StataCorp LP, 2011.

24. Raciti, S. M., Burgin, A. J., Groffman, P. M., Lewis, D. N. and Fahey, T. J., Denitrification in suburban lawn soils. J. Environ. Qual., 2011, 40, 1932-1940.

25. Bergstrom, D. W., Tenuta, M. and Beauchamp, E. G., Nitrous oxide production and flux from soil under sod following application of different nitrogen fertilizers. Commun. Soil Sci. Plant Analysis, 2001, 32, 553-570.

26. Thapa, R., Chatterjee, A., Awale, R., McGranahan, D. A. and Daigh, A., Effect of enhanced efficiency fertilizers on nitrous 


\section{RESEARCH ARTICLES}

oxide emissions and crop yields: a meta-analysis. Soil Sci. Soc. Am. J., 2016, 80, 1121-1134.

27. Bouwman, A. F., Boumans, L. J. M. and Batjes, N. H., Emissions of $\mathrm{N}_{2} \mathrm{O}$ and $\mathrm{NO}$ from fertilized fields: summary of available measurement data. Global Biogeochem. Cycles, 2002, 16.

28. Linquist, B. A., Adviento-Borbe, M. A., Pittelkow, C. M., van Kessel, C. and van Groenigen, K. J., Fertilizer management practices and greenhouse gas emissions from rice systems: a quantitative review and analysis. Field Crops Res., 2012, 135, 10-21.

29. Groffman, P. M., Williams, C. O., Pouyat, R. V., Band, L. E. and Yesilonis, I. D., Nitrate leaching and nitrous oxide flux in urban forests and grasslands. J. Environ. Qual., 2009, 38, 1848-1860.

30. Crane, J. W., The Thermo-climatic cost of a lush, green lawn: characterizing $\mathrm{N}_{2} \mathrm{O}$ emissions from lawns, Doctoral dissertation, Vanderbilt University, 2014.

31. LeMonte, J. J., Jolley, V. D., Summerhays, J. S., Terry, R. E. and Hopkins, B. G., Polymer coated urea in turfgrass maintains vigor and mitigates nitrogen's environmental impacts. PLOS ONE, 2016, 11, e0146761.

32. Gillette, K., The Colorado Golf Carbon Project, Doctoral dissertation, Colorado State University, 2014.

33. Matthias, A. D., Blackmer, A. M. and Bremner, J. M., Diurnal variability in the concentration of nitrous oxide in surface air. $G e$ ophys. Res. Lett., 1979, 6, 441-443.

34. Livesley, S. J., Dougherty, B. J., Smith, A. J., Navaud, D., Wylie, L. J. and Arndt, S. K., Soil-atmosphere exchange of carbon dioxide, methane and nitrous oxide in urban garden systems: impact of irrigation, fertiliser and mulch. Urban Ecosyst., 2010, 13, 273 293
35. McPhillips, L. E., Groffman, P. M., Schneider, R. L. and Walter, M. T., Nutrient cycling in grassed roadside ditches and lawns in a suburban watershed. J. Environ. Qual., 2016, 45, 1901-1909.

36. Garrison, M. and Soldat, D., Nitrous oxide emissions from coolseason turfgrass managed with organic and synthetic nitrogen fertilizers. Turfgrass Environ. Res. Online, 2014, 13.

37. Walker, K. S. and Smith, K. E., The Effects of Cultivation Practices and Fertilizer use on the Mitigation of Greenhouse Gas Emissions from Kentucky Bluegrass Athletic Fields, University of Minnesota, 2014.

38. Braun, R. and Bremer, D., Nitrous Oxide Emissions in Turfgrass: Effects of Irrigation and Nitrogen Fertilization, Kansas State University, 2016.

39. Nahas, A., Walker, J. T., Yelverton, F. and Aneja, V. P., Characterization of reactive nitrogen emissions from turfgrass. In AGU Fall Meeting Abstracts, 2018.

ACKNOWLEDGEMENTS. This paper is based on work conducted with support from the National Institute of Advanced Studies (NIAS), IISc Campus, Bengaluru, India. We are grateful to Prof. Dilip Ahuja for his valuable comments, and suggestions. We also thank Mr Rakesh Tiwari for his contribution in developing this work.

Received 22 December 2019; accepted 2 January 2020

doi: $10.18520 / \mathrm{cs} / \mathrm{v} 118 / \mathrm{i} 8 / 1219-1226$ 